\title{
Article
}

\section{Efficient hydrogen peroxide (HO) synthesis by CaSnO via two-electron water oxidation reaction}

Ting Kang, Bei Li, Qinglan Hao, Weijie Gao, Feng Bin, Kwun Nam Hui, Baojuan Dou, and Dong Fu

ACS Sustainable Chem. Eng., Just Accepted Manuscript • DOI: 10.1021/

acssuschemeng.0c05449 • Publication Date (Web): 06 Sep 2020

Downloaded from pubs.acs.org on September 12, 2020

\section{Just Accepted}

"Just Accepted" manuscripts have been peer-reviewed and accepted for publication. They are posted online prior to technical editing, formatting for publication and author proofing. The American Chemical Society provides "Just Accepted" as a service to the research community to expedite the dissemination of scientific material as soon as possible after acceptance. "Just Accepted" manuscripts appear in full in PDF format accompanied by an HTML abstract. "Just Accepted" manuscripts have been fully peer reviewed, but should not be considered the official version of record. They are citable by the Digital Object Identifier (DOI®). "Just Accepted" is an optional service offered to authors. Therefore, the "Just Accepted" Web site may not include all articles that will be published in the journal. After a manuscript is technically edited and formatted, it will be removed from the "Just Accepted" Web site and published as an ASAP article. Note that technical editing may introduce minor changes to the manuscript text and/or graphics which could affect content, and all legal disclaimers and ethical guidelines that apply to the journal pertain. ACS cannot be held responsible for errors or consequences arising from the use of information contained in these "Just Accepted" manuscripts. 


\title{
Efficient hydrogen peroxide $\left(\mathrm{H}_{2} \mathrm{O}_{2}\right)$ synthesis by $\mathrm{CaSnO}_{3}$ via two-
}

\section{electron water oxidation reaction}

\author{
Ting Kang ${ }^{\dagger}$, Bei $\mathrm{Li}^{\dagger}$, Qinglan Hao ${ }^{\dagger}$, Weijie Gao ${ }^{\dagger}$, Feng Bin ${ }^{\star}$, Kwun Nam Hui ${ }^{\#}$, \\ Dong $F u^{\S *}$ and Baojuan Dou ${ }^{\dagger *}$ \\ $\uparrow$ Tianjin Key Laboratory of Brine Chemical Engineering and Resource Eco-utilization, \\ College of Chemical Engineering and Materials Science, Tianjin University of Science and \\ Technology, Tianjin 300457, P. R. China; \\ \$ State Key Laboratory of High-Temperature Gas Dynamics, Institute of Mechanics, Chinese \\ Academy of Sciences, Beijing 100190, P.R. China; \\ \# Institute of Applied Physics and Materials Engineering, University of Macau, Avenida da \\ Universidade, Taipa, Macau 999078, P.R. China; \\ $\S$ Tianjin Weiming Technology Co., Ltd., Tianjin 300384, P. R. China. \\ *Correspondence authors. \\ Email address: bjdou@tust.edu.cn (Baojuan Dou) orfudongimu@yahoo.com (Dong Fu)
}




\begin{abstract}
Electrochemical in-situ hydrogen peroxide $\left(\mathrm{H}_{2} \mathrm{O}_{2}\right)$ generation from two-electron water oxidation reaction (2e-WOR) is a challenge, not only on catalyst selection, also the electrode making. Herein, the $\mathrm{H}_{2} \mathrm{O}_{2}$ electro-catalyst $\mathrm{CaSnO}_{3}$ nanoparticles were prepared by low cost glucose as an agent and characterized by XRD, TG-DSC, FT-IR, SEM, TEM and XPS. The active sites for the $\mathrm{OH}^{-}$adsorption on the surface $\mathrm{CaSnO}_{3}$ (121) was identified by density functional theory (DFT) calculation and the corresponding reaction mechanism of $\mathrm{H}_{2} \mathrm{O}_{2}$ formation was proposed. The $\mathrm{CaSnO}_{3}$ nanoparticles can be formed from $650{ }^{\circ} \mathrm{C}$ to $850{ }^{\circ} \mathrm{C}$ and the particles sizes are in the range of $27.2-37.3 \mathrm{~nm}$. The mechanism of catalyst formation is that species of $\mathrm{Ca}$ and $\mathrm{Sn}$ reacted with oxygen to generate $\mathrm{CaO}$ and $\mathrm{SnO}_{2}$ during low temperature calcination and $\mathrm{CaSnO}_{3}$ generated during high temperature calcination. The active sites are the coordination-unsaturated $\mathrm{Sn}$ ions which easily adsorb the negative charge $\mathrm{OH}^{-}$from solution forming $\mathrm{OH}^{*}$ intermediate and two adsorbed $\mathrm{OH}^{*}$ can combine to generate a neutral $\mathrm{H}_{2} \mathrm{O}_{2}$ molecule. $\mathrm{H}_{2} \mathrm{O}_{2}$ generation rate over $\mathrm{CaSnO}_{3}$ calcinated at $850{ }^{\circ} \mathrm{C}$ is $347.7 \mu \mathrm{mol} \cdot \mathrm{min}^{-1} \cdot \mathrm{g}^{-1}$ at 2.6 $\mathrm{V}$ vs $\mathrm{Ag} / \mathrm{AgCl}$ under dark. The work opens an in-situ $\mathrm{H}_{2} \mathrm{O}_{2}$ generation route, directly water oxidation, with wide applications prospects.
\end{abstract}

Keywords: $\mathrm{CaSnO}_{3}$ nanoparticles, in-situ $\mathrm{H}_{2} \mathrm{O}_{2}$ generation, two-electron water oxidation reaction, DFT, Vacancy oxygen, Calcination 


\section{Introduction}

Hydrogen peroxide $\left(\mathrm{H}_{2} \mathrm{O}_{2}\right)$, as an elegant and green oxidation reagent, has widely used in the areas of chemical engineering and environmental protection, ${ }^{1,2}$ because $\mathrm{H}_{2} \mathrm{O}_{2}$ non-selectively mineralizes most organic pollutants even for highly recalcitrant organic compounds by producing the highly reactive hydroxyl in-situ radicals $\left(\cdot \mathrm{OH}\right.$ etc.). ${ }^{3}$ However, $\mathrm{H}_{2} \mathrm{O}_{2}$ usually depends on the large-scale industrial production ${ }^{4}$ achieved through the large-scale concentrated anthraquinone process, which requires costly plants and infrastructures. ${ }^{5} \mathrm{H}_{2} \mathrm{O}_{2}$ also is unstable and potentially explosive at high concentrations, imposing safety challenges for usage, transportation and storage. Therefore, in-situ production of $\mathrm{H}_{2} \mathrm{O}_{2}$ is particularly important for the many applications such as disinfection and wastewater treatment.

A small amount of $\mathrm{H}_{2} \mathrm{O}_{2}$ can be generated in-situ in the water during the electrochemical processes. ${ }^{6,7}$ In the theory, there are two types of electrochemical pathways for $\mathrm{H}_{2} \mathrm{O}_{2}$ electrochemical generation, which are direct two-electron oxygen reduction reaction $(\mathrm{ORR})^{8}$ and two-electron water oxidation reaction $(2 \mathrm{e}-\mathrm{WOR})^{9}$ pathways. However, $\mathrm{H}_{2} \mathrm{O}_{2}$ generation by ORR requires gas-diffusion electrodes and high cost precious metal electrodes for the reduction of dissolve $\mathrm{O}_{2}$ in water. ${ }^{10}$ Due to the lower $\mathrm{O}_{2}$ concentration dissolved in the water, the efficiency of $\mathrm{H}_{2} \mathrm{O}_{2}$ production is not very high. Therefore, the 2e-WOR process probably will be high effective for $\mathrm{H}_{2} \mathrm{O}_{2}$ production since water is the reactant not depending on $\mathrm{O}_{2}$ solubility in the water.

Nevertheless, from the standard electrode potentials about $\mathrm{O}_{2}-\mathrm{H}_{2} \mathrm{O}_{2}-\mathrm{H}_{2} \mathrm{O}$ system (Equation S1-6, See Supporting Information), water is oxidized to $\mathrm{O}_{2}$ (Equation S2) is thermodynamic favorite comparing with the 2e-WOR to $\mathrm{H}_{2} \mathrm{O}_{2}$ (Equation $\mathrm{S} 1$ ) due to the lower standard electrode potentials for $\mathrm{O}_{2}$ evolution. Therefore, 2e-WOR to $\mathrm{H}_{2} \mathrm{O}_{2}$ is considered as a much more difficult 
process. ${ }^{11}$ A main challenge for $2 \mathrm{e}-\mathrm{WOR}$ to $\mathrm{H}_{2} \mathrm{O}_{2}$ is to find a selective and efficient catalyst. ${ }^{12}$ Some high cost precious metals, such as $\mathrm{Pt}, \mathrm{Au}, \mathrm{Pd}$ etc., ${ }^{11,13}$ and transition metal oxides, such as $\mathrm{WO}_{3}, \mathrm{BiVO}_{4}, \mathrm{SnO}_{2}, \mathrm{TiO}_{2}, \mathrm{Co}_{3} \mathrm{O}_{4}, \mathrm{La}_{2} \mathrm{O}_{3}, \mathrm{Al}_{2} \mathrm{O}_{3}$, and $\mathrm{ZrO}_{2},{ }^{14,15}$ were proved with weakly catalytic efficiency. $\mathrm{BiVO}_{4}$ is considered as a candidate, but the optimal bias range for $\mathrm{BiVO}_{4}$ is wide to produce $\mathrm{H}_{2} \mathrm{O}_{2}$ in dark $(\sim 2.9-3.3 \mathrm{~V} \text { vs the reversible hydrogen electrode }(\mathrm{RHE}))^{16}$ and $\mathrm{BiVO}_{4}$ also is toxic and notoriously poor stability. ${ }^{17}$ These weaknesses of precious metals and metal oxides catalysts hinder their large scale applications for $2 \mathrm{e}-\mathrm{WOR}$ to $\mathrm{H}_{2} \mathrm{O}_{2}$. It is urgent to identify a stable and nontoxic electro-catalyst for $2 \mathrm{e}-\mathrm{WOR}$. Park et al. ${ }^{18}$ recently reported that $\mathrm{CaSnO}_{3}$ was an effective 2e-WOR catalyst with high activity and low cost, outperforming $\mathrm{BiVO}_{4}$ in all aspects. However, the preparation $\mathrm{CaSnO}_{3}$ and electrode were the complicated process, such as dissolving chemicals in $\mathrm{H}_{2} \mathrm{O}_{2}$ solution, reflux, precipitate, re-distribute in organic solvent, spin on expensive and fragile $\mathrm{F}: \mathrm{SnO}_{2}$ (FTO) conductive glass and anneal. These will obstruct the $\mathrm{CaSnO}_{3}$ catalyst application.

In this paper, $\mathrm{CaSnO}_{3}$ catalyst for $2 \mathrm{e}-\mathrm{WOR}$ was prepared by simple and low cost preparation method. The effects of calcination temperatures on the phase composition and crystallinity of the catalysts were studied. The as-prepared $\mathrm{CaSnO}_{3}$ catalysts were coated on the carbon paper for electrode with a low cost and easy process. The electro-catalytic activity of 2e-WOR over $\mathrm{CaSnO}_{3}$ with different calcination temperatures was measured. Relationship was discussed between vacancy oxygen concentration and catalytic activity. To identify the active sites for the $\mathrm{OH}^{-}$adsorption on the surface $\mathrm{CaSnO}_{3}$ during 2e-WOR to $\mathrm{H}_{2} \mathrm{O}_{2}$ generation, density functional theory (DFT) was employed. In-situ $\mathrm{H}_{2} \mathrm{O}_{2}$ generation by $\mathrm{CaSnO}_{3}$ catalytic water oxidation reaction makes a chance to benefit applications in sustainable development, such as water pollution control. 


\section{Experimental}

All chemicals purchased were analytical grade and used as received without further purification or modification.

\section{Preparation}

\section{Synthesis of catalysts}

$\mathrm{CaSnO}_{3}$ nanoparticles were synthesized by a route as follows. Firstly, $38.05 \mathrm{~g}$ of glucose (Jiang Tian Chemical Reagent Co., Ltd) was dissolved in $60 \mathrm{~mL}$ distilled water at room temperature. 2.15g of $\mathrm{CaCl}_{2}$ (Sinopharm Chemical Reagent Co., Ltd) and $4.37 \mathrm{~g}$ of $\mathrm{SnCl}_{2} \cdot 2 \mathrm{H}_{2} \mathrm{O}$ (Sinopharm Chemical Reagent Co., Ltd) were dissolved in $5 \mathrm{~mL}$ concentrated hydrochloric acid solution and added into the glucose solution, then stirred at $30^{\circ} \mathrm{C}$ to achieve transparent solution. The obtained solution was heated at $80{ }^{\circ} \mathrm{C}$ for 24 hours, resulting in a thick gel which eventually turned into a brown fluffy mass. Finally, the product was ground and calcined at various temperatures $\left(550-850^{\circ} \mathrm{C}\right)$ for $2 \mathrm{~h}$ in air. The catalysts were denoted CS-550, CS-650, CS-750, CS-800 and CS-850, for calcination temperature of 550, 650, 750, 800 and $850{ }^{\circ} \mathrm{C}$, respectively.

\section{Preparation of working electrode}

The working electrodes were fabricated by compressing the mixture of $50 \mathrm{wt} . \%$ active materials $\left(\mathrm{CaSnO}_{3}\right), 40$ wt.\% Super P carbon, and $10 \mathrm{wt} \%$ polyvinylidene fluoride (PVDF). And then Nmethyl pyrrolidinone (NMP) was added to form slurry and coated on carbon paper with thickness of $300 \mu \mathrm{m}$.

\section{Catalyst characterization}


The phase and structure of the samples were analyzed by X-ray diffractmeter. X-ray diffraction (XRD) patterns were recorded using a Bruker D8-Focus (Germany) diffractometer with $\mathrm{Cu} \mathrm{K \alpha}$ radiation. The measurements were conducted in the $2 \theta$ range from $20^{\circ}$ to $70^{\circ}$ with a scanning rate of 4 \% min. The crystallite size of $\mathrm{CaSnO}_{3}$ was calculated using the Scherrer's equation, $D=K \gamma / \beta \cos \theta$, where $K$ is a constant, 0.89. $\gamma$ is $0.154056 \mathrm{~nm}$, the wavelength of $\mathrm{Cu} K \alpha$ radiation. $\beta$ the full width at half maximum (FWHM) in radians obtained using Jade software, and $\theta$ the scattering angle. Fourier transform infrared spectra (FT-IR) were obtained in the range of $4000-400 \mathrm{~cm}^{-1}$ on a Shimadzu IR-Prestige-21 spectrometer. The surface morphology of the samples was carried out by scanning electron microscopy (SEM). SEM photographs were taken with a field-emission microscope (JEOL, JSM-6390LV) using an accelerating voltage of $15 \mathrm{kV}$. The detailed microstructure of the samples was observed by transmission electron microscopy (TEM). TEM images were obtained by a JEOL model JEM 2010 FEF instrument at the accelerating voltage of $200 \mathrm{kV}$. The elements in the sample and their valence states were analyzed by X-ray photoelectron spectroscopy (XPS). XPS was conducted via an Ulvacphi PHI Quantera SXM (Japan). The X-ray source was an Mg anode target (350 eV). The binding energy values of each species were corrected with an internal standard of C1s $\left(E_{\mathrm{b}}=284.8 \mathrm{eV}\right)$.

\section{Catalytic activity measurement}

The electrochemical performance of the $\mathrm{CaSnO}_{3}$ working electrodes were measured in a homemade system of glass reactor enclosing $20 \mathrm{~mL}$ of $\mathrm{KHCO}_{3}(2 \mathrm{M})$ at room temperature under dark condition by covering aluminum foils. The electrochemical measurements were carried out over potentiostat (Chen Hua CHI400C, Shanghai) with a three-electrode system, in which the $\mathrm{Ag} / \mathrm{AgCl}$ electrode was used as a reference electrode and graphite rod as the counter electrode. $\mathrm{H}_{2} \mathrm{O}_{2}$ concentration was determined by potassium permanganate titration. ${ }^{19}$ 


\section{Method and model}

The adsorption of $\mathrm{OH}^{-}$and $\mathrm{H}_{2} \mathrm{O}_{2}$ on the typical surface $\mathrm{CaSnO}_{3}$ (121) was calculated systematically using DFT calculation as seen in Supporting Information.

\section{Results and discussion}

\section{$\mathrm{CaSnO}_{3}$ nanoparticle formation}

The phase evolution of the catalysts was characterized by XRD.

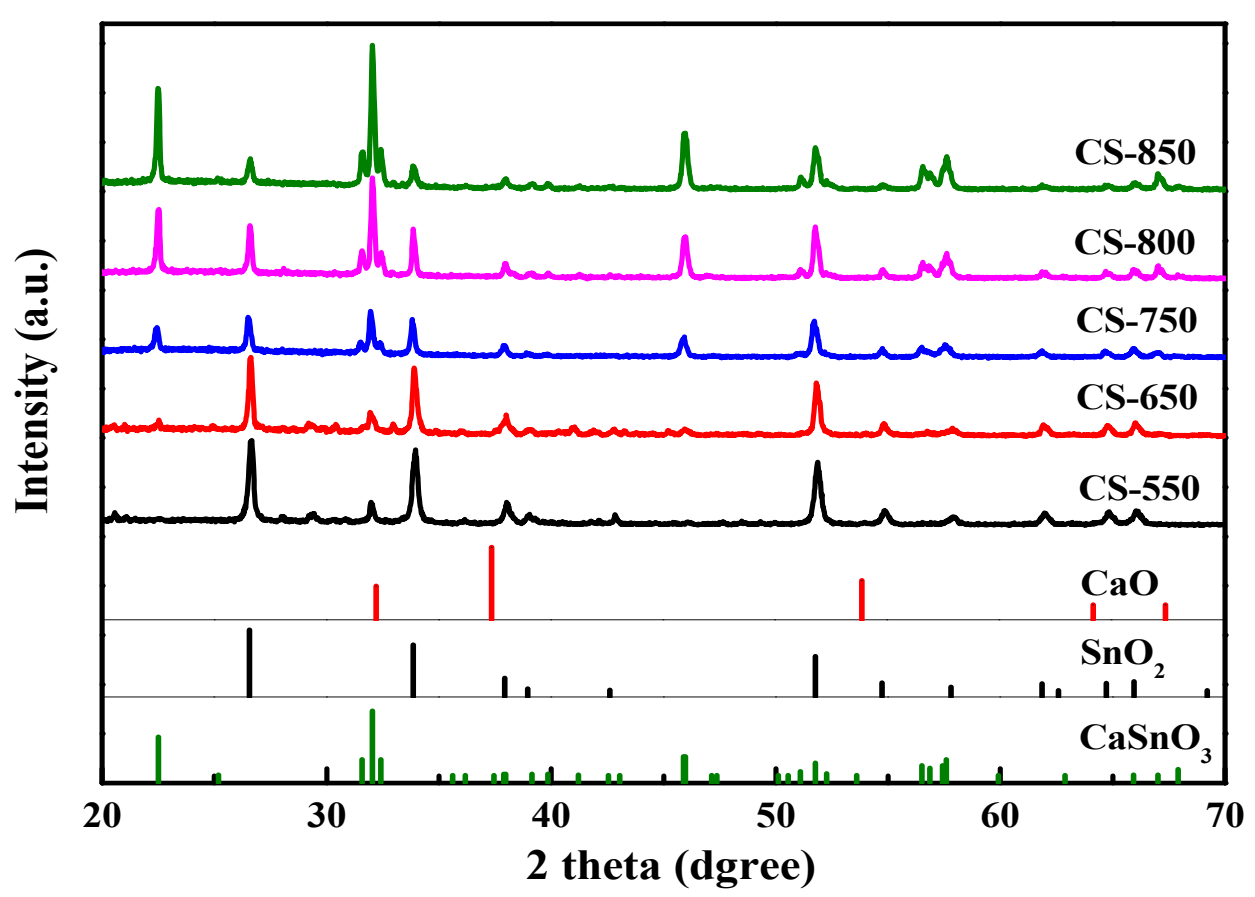

Figure 1 XRD patterns of different catalysts with various calcination temperatures.

Figure 1 illustrates the XRD patterns of catalysts obtained at various calcination temperatures for $2 \mathrm{~h}$. It can be seen that calcination temperature significantly influences the crystal structure of $\mathrm{CaSnO}_{3}$. With calcination temperature of $550{ }^{\circ} \mathrm{C}$, just $\mathrm{SnO}_{2}$ peaks at $26.6^{\circ}, 33.8^{\circ}, 51.8^{\circ}$ and a weak $\mathrm{CaSnO}_{3}$ peak at $32.0^{\circ}$ are presented in the pattern. The intensity of the $\mathrm{CaSnO}_{3}$ peak at $32.0^{\circ}$ increases and another weak peak at $22.5^{\circ}$ of $\mathrm{CaSnO}_{3}$ is observed with the temperature 
increasing to $650^{\circ} \mathrm{C}$. When the sample is calcined at $750{ }^{\circ} \mathrm{C}$, most of $\mathrm{CaSnO}_{3}$ peaks appear and are readily indexed to a pure orthorhombic $\mathrm{CaSnO}_{3}$ with perovskite structure (space group: P212121 (19), JCPDS31-0312) ${ }^{20}$ validating that the $\mathrm{CaSnO}_{3}$ crystals are obviously formed around $750{ }^{\circ} \mathrm{C}$. At 800 and $850{ }^{\circ} \mathrm{C}$, the intensity of the $\mathrm{CaSnO}_{3}$ peaks increase and become sharper, indicating the perfect crystal of $\mathrm{CaSnO}_{3}$ and the growth of particles size. More perfect crystals in $\mathrm{CaSnO}_{3}$ will enhance the catalyst activity. With increasing the temperature from 650 ${ }^{\circ} \mathrm{C}$ to $850{ }^{\circ} \mathrm{C}$, the peaks correspond to the $\mathrm{CaSnO}_{3}$ at $22.5^{\circ}, 32.0^{\circ}, 46.0^{\circ}, 56.5^{\circ}, 57.6^{\circ}$ become stronger. The intensity of $\mathrm{SnO}_{2}$ peaks of samples becomes weaker with the calcination temperature increasing from 650 to $850{ }^{\circ} \mathrm{C}$, although slightly stronger for CS-800, but not changed the trend. Although the intensity of $\mathrm{SnO}_{2}$ decreases with increasing the calcination temperature, the $\mathrm{SnO}_{2}$ peaks still exist even at $850{ }^{\circ} \mathrm{C}$, demonstrating a few $\mathrm{SnO}_{2}$ impurities in the catalysts with different calcination temperature. It is important to note that the peak of $\mathrm{CaO}$ does not appear in the XRD pattern, implying that it is highly dispersed or amorphous.

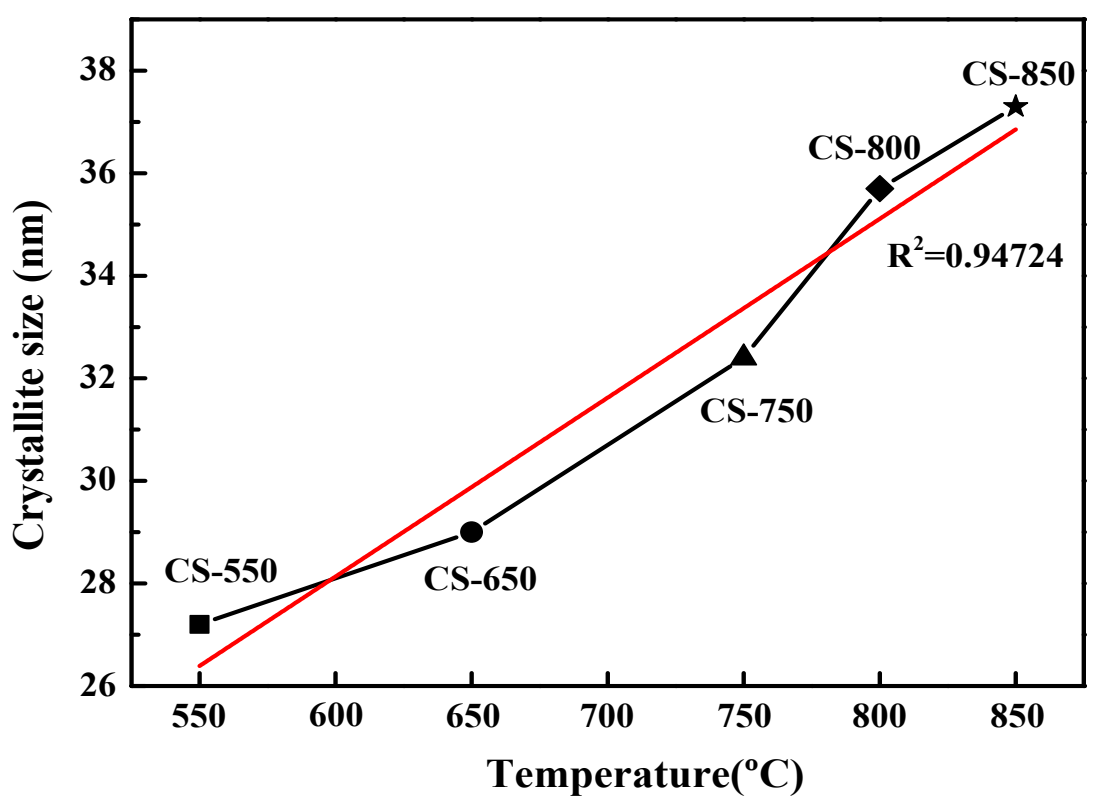

Figure 2 Crystallite size vs calcination temperature. 
The estimated crystallite size calculated by Scherrer equation versus calcination temperature is shown in Figure 2. The relationship between particle sizes and the calcination temperature is approximately linear, which can be used for particle size adjustment for further application. According to the XRD patterns, the calcination temperature plays an important role on the phase composition and the particle size of $\mathrm{CaSnO}_{3}$ catalyst. With the calcination, calcium and stannum form metal oxides, and the structure of these oxides changes gradually forming the $\mathrm{CaSnO}_{3}$ crystals which grow up with increasing the calcination temperature.

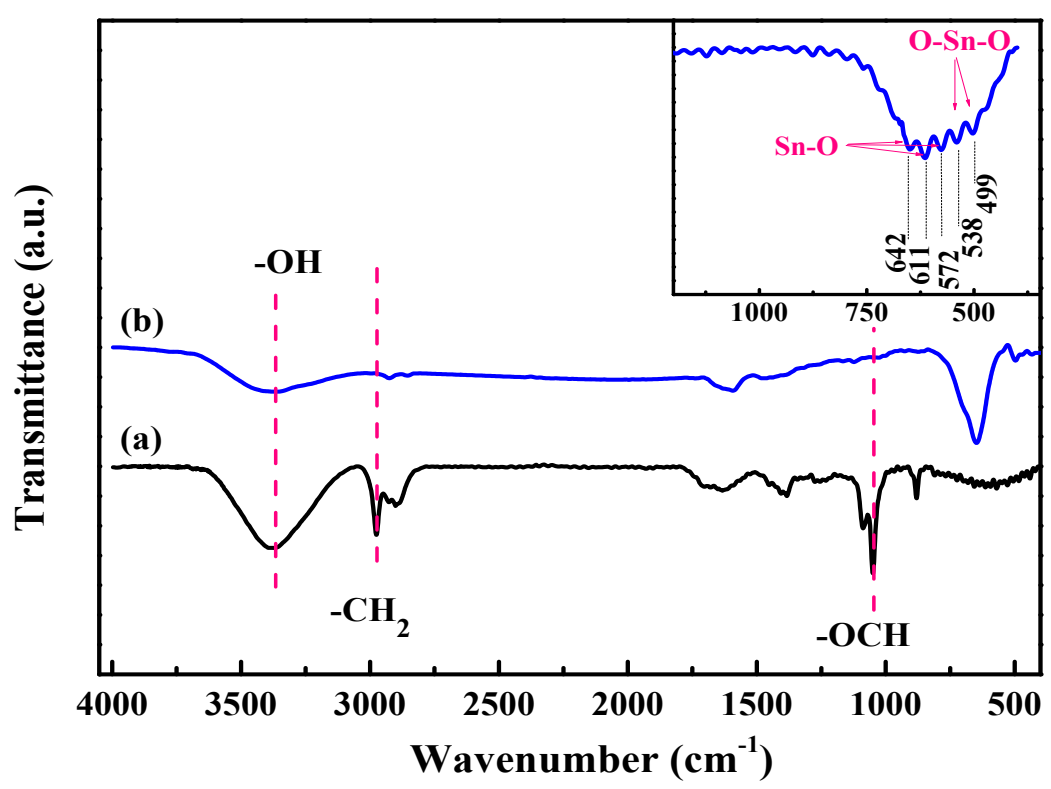

Figure 3 FT-IR spectrum (a) of the precursor and (b) the CS-850.

Figure 3 shows FT-IR spectrum of the precursor and the $\mathrm{CaSnO}_{3}$ calcined at $850^{\circ} \mathrm{C}$. As shown in figure, the bands of $-\mathrm{CH}_{2}\left(2975 \mathrm{~cm}^{-1}\right)$ and $-\mathrm{OCH}\left(1043 \mathrm{~cm}^{-1}\right)$ groups of the precursor are present. These bands are from glucose and disappear after the sample is calcined at $850{ }^{\circ} \mathrm{C}$, primarily due to the destruction of the glucose. The band at $642 \mathrm{~cm}^{-1}$ in the mid-IR spectrum of $\mathrm{CaSnO}_{3}$ can be assigned to the stretching mode of perovskite structure of Sn-O. ${ }^{21,22}$ For the 
spectrum obtained in the far-IR range (inset of Figure 3), the bands at 499 and $538 \mathrm{~cm}^{-1}$ are corresponded to the bending mode of perovskite structure of O-Sn-O,22 and bands at 572, 611 and $642 \mathrm{~cm}^{-1}$ are referred to the stretching modes of perovskite structure Sn-O bonds. ${ }^{22,23}$ It can be seen clearly that after calcination at $850{ }^{\circ} \mathrm{C}$, the characteristic adsorption bands of metaloxygen bonds are formed, which matches the FT-IR spectrum perovskite structure $\mathrm{CaSnO}_{3}$, confirming the formation of $\mathrm{CaSnO}_{3}$ under the preparation conditions in this study.
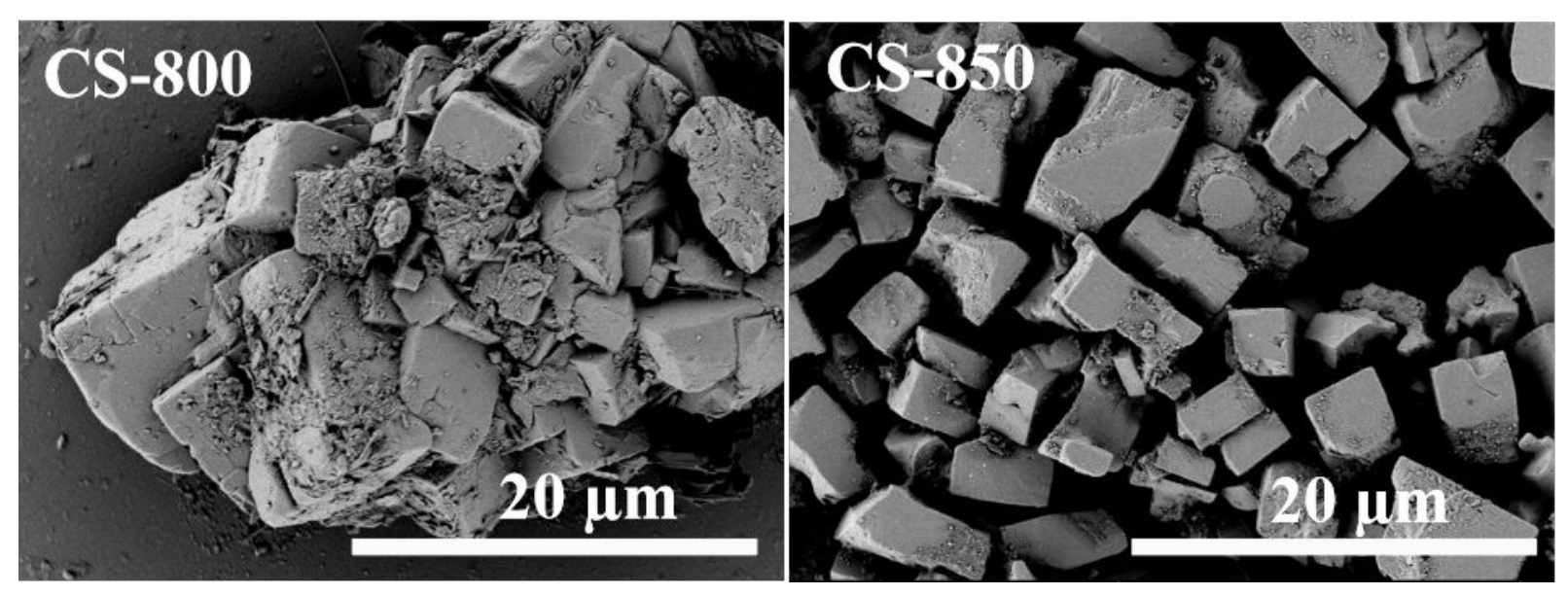

Figure 4 SEM images of CS-800 and CS-850.
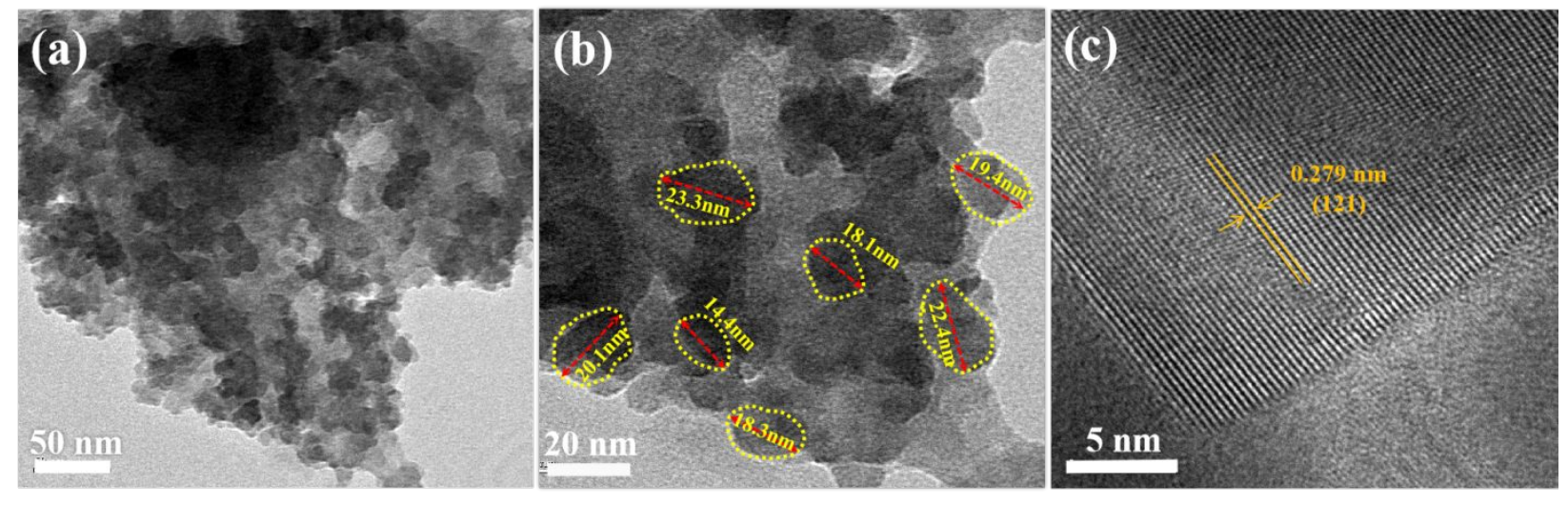

Figure 5 TEM image (a), and HRTEM images of CS-850 (b and c).

With the increase of calcination temperature, the morphology of the samples changes obviously. 
At $550{ }^{\circ} \mathrm{C}, 650^{\circ} \mathrm{C}$ and $750{ }^{\circ} \mathrm{C}$, the morphology of samples is amorphous (see Figure $\mathrm{S} 1$ ), probably owing that the glucose is not completely oxidized and formed charcoal. Based on the XRD results, a small amount of $\mathrm{CaSnO}_{3}$ is still formed even with lower calcination temperature $\left(650{ }^{\circ} \mathrm{C}\right)$. Hence, the white spots on the surface probably are the aggregated $\mathrm{CaSnO}_{3}$ particles, due to the amount of white points increase with the increase of calcination temperature. Figure 4 shows the SEM image of the catalysts calcined at 800 and $850^{\circ} \mathrm{C}$, and the morphology changes from amorphous to cubic, implying that the charcoal is removed and the crystals of catalyst become more perfectly. Meanwhile, the colors of the samples change from dark to grey to white with increasing calcination temperature from $550-850{ }^{\circ} \mathrm{C}$ by naked eye observation. From the SEM, the particle size of CS-850 is much higher than the results from Scherrer's equation calculation, probably due to the aggregation.

The TEM images of the catalysts prepared at $850^{\circ} \mathrm{C}$ are shown in Figure 5, and it shows that the nanoparticles of the catalyst are formed. In HRTEM images of Figure 5 (b) and (c), the shape of particle is irregular. The lattice fringe of $0.279 \mathrm{~nm}$ corresponds to the $\mathrm{d}_{121}$-spacing of $\mathrm{CaSnO}_{3}$, indicating that the main structural phase is $\mathrm{CaSnO}_{3}$ in accordance with the results of XRD and FT-IR.

\section{Mechanism of $\mathrm{CaSnO}_{3}$ nanoparticles formation}

The mechanism of the $\mathrm{CaSnO}_{3}$ nanoparticles synthesized is similar as the sol-gel mechanism. In general, the sol-gel process involves conversion of monomers into a colloidal solution (sol) that acts as the precursor for an integrated network (or gel) of either discrete particles or network polymers. ${ }^{24}$ In this chemical procedure, the sol gradually evolves towards the formation of a gellike diphasic system containing both liquid and solid phases, and the morphologies range from 
discrete particles to continuous polymer networks. Removal of the solvent requires a drying process, which is typically accompanied by a significant amount of shrinkage and densification. The rate at which the solvent can be removed is ultimately determined by the distribution of porosity in the gel.

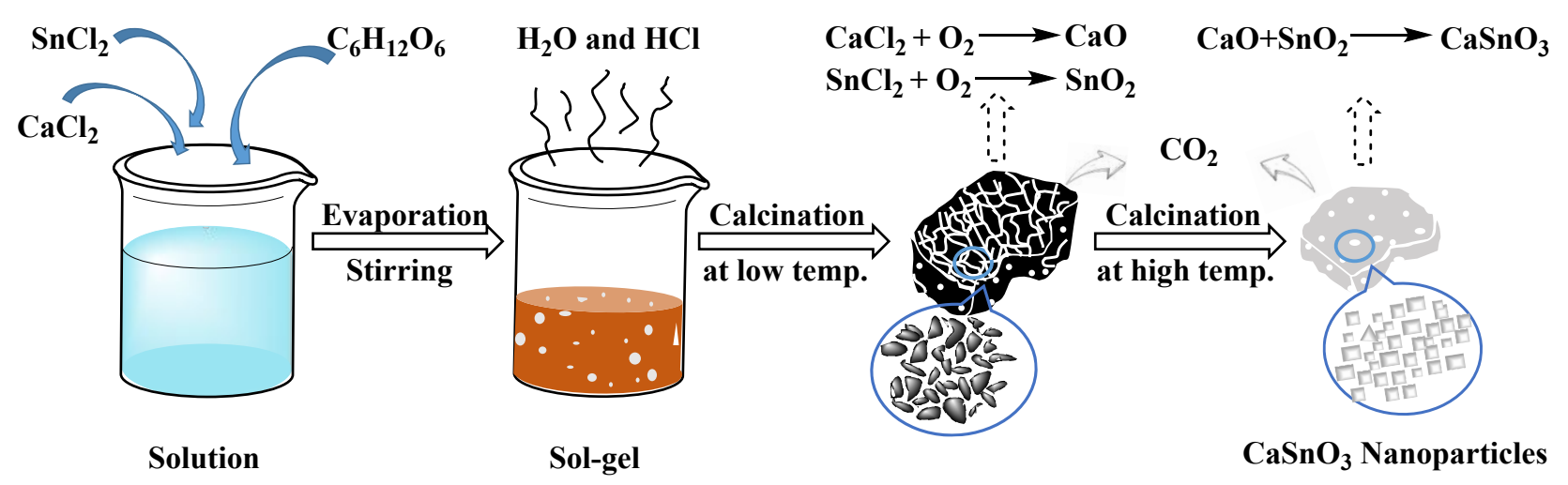

Figure 6 Schematic illustration of procedures for preparing $\mathrm{CaSnO}_{3}$ nanoparticles.

From observation of the experiments of preparation and TG-DSC (See Figure S3), FT-IR, SEM and TEM analysis, the mechanism of $\mathrm{CaSnO}_{3}$ nanoparticles formation is proposed in Figure 6. When $\mathrm{Ca}^{2+}, \mathrm{Sn}^{2+}$ and glucose were dissolved in the water, a transparent and homogeneous sample solution was obtained. Removal of the water (also $\mathrm{HCl}$ ) in drying process forms a thick gel which eventually turned into a brown fluffy mass precursor. When precursor gel was annealed, species of $\mathrm{Ca}$ and $\mathrm{Sn}$ (chloride) reacted with oxygen to form $\mathrm{CaO}$ and $\mathrm{SnO}_{2}$ at low temperature calcination. And then, with increasing the calcination temperature, $\mathrm{CaO}$ reacted with the $\mathrm{SnO}_{2}$ to form $\mathrm{CaSnO}_{3}$. The color of the products changed from dark to grey and to white with temperature increasing. The dark product is due to the glucose dehydration to form charcoal which was oxidized incompletely. With increasing the calcination temperature, the charcoal was oxidized continually until completely disappeared with color change from dark to grey, finally to 
white $\mathrm{CaSnO}_{3}$.

\section{Surface structure of catalyst by XPS}

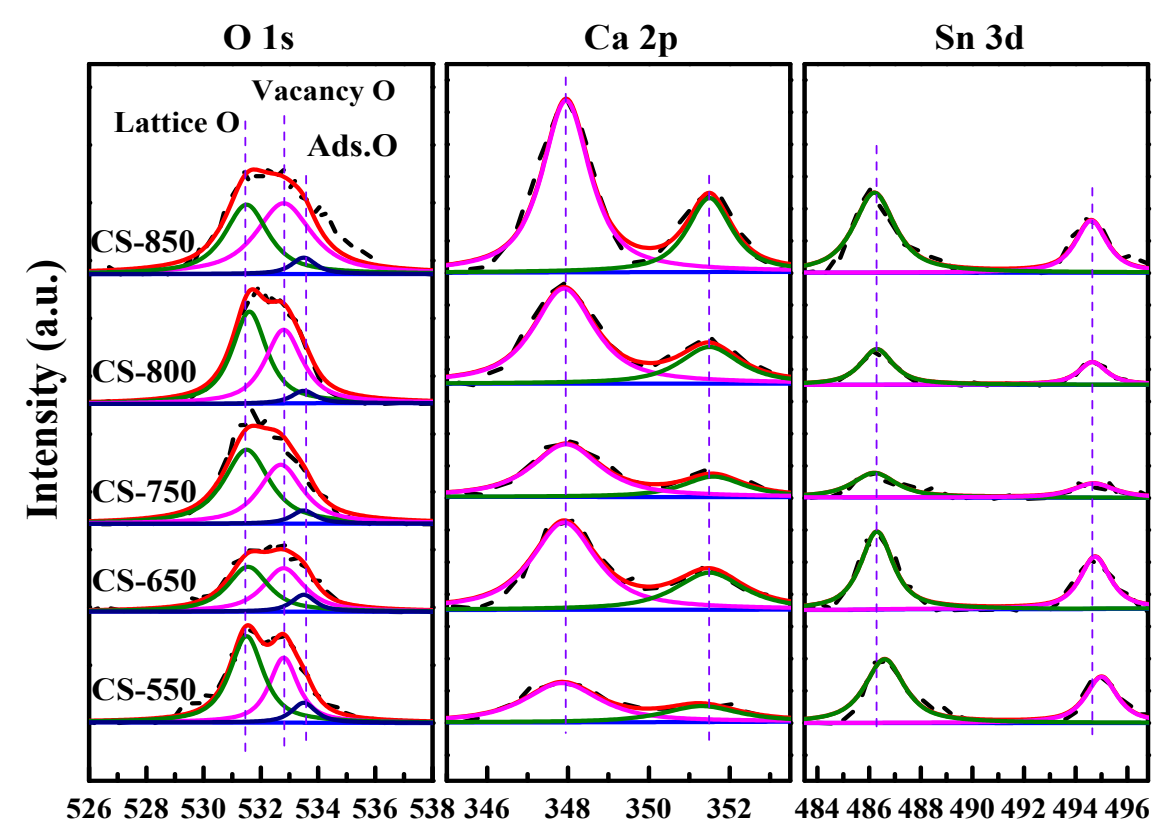

Figure 7 XPS spectra of samples calcined at various temperatures.

The chemical composition of sample surface was confirmed using XPS. The high-resolution XPS spectra of $\mathrm{Ca}$, Sn and $\mathrm{O}$ elements are revealed in Figure 7. As shown in the figure, the best fit of XPS spectra of $\mathrm{Ca} 2 \mathrm{p}$ exhibits two contributions, $\mathrm{Ca} 2 \mathrm{p}_{3 / 2}$ and $\mathrm{Ca} 2 \mathrm{p}_{1 / 2}$ (resulting from the spin orbit splitting), located at respectively 347.9 and $351.5 \mathrm{eV}$. The binding energies separation between $\mathrm{Ca} 2 \mathrm{p}_{3 / 2}$ and $\mathrm{Ca} 2 \mathrm{p}_{1 / 2}$ is $3.6 \mathrm{eV}$ for all of the samples, which is in good consistency with BE values of reported literature. ${ }^{25,26}$ Except for CS-550, Sn 3d peaks are at 486.3 and $494.6 \mathrm{eV}$ for others, corresponding to the oxidized states of perovskite structure (486.4 and $494.8 \mathrm{eV}$, respectively). ${ }^{25,26}$ For CS-550, the Sn $3 \mathrm{~d}$ binding energy values are 486.6 and $494.9 \mathrm{eV}$. The slight shift in $\mathrm{Sn} 3 \mathrm{~d}$ for $550{ }^{\circ} \mathrm{C}$ sample probably exists more electronegative $\mathrm{Cl}^{-}$in the raw material leading to binding energy increasing due to lower calcination temperature. ${ }^{27}$ It is seen 
that $\mathrm{O} 1 \mathrm{~s}$ spectra shows three peaks at $531.5,532.8$ and $533.7 \mathrm{eV}$ for all of the catalysts. The peaks at $531.5 \mathrm{eV}$ and $532.8 \mathrm{eV}$ can be associated with the lattice $\mathrm{O}^{28}$ and the oxygen vacancies in the perovskite oxide structure $\left(\mathrm{ABO}_{3}\right),{ }^{26}$ respectively. And the $533.7 \mathrm{eV}$ peak is corresponding to the surface adsorption oxygen. ${ }^{29}$

To estimate the relative vacancy oxygen concentration in this study, ratio of vacancy oxygen is used, which is $\mathrm{O} 1 \mathrm{~s}$ (vacancy oxygen)/O 1s (lattice oxygen + adsorption oxygen). The ratio of vacancy oxygen values of the samples and their corresponding parameters are summarized in Table 1. It is found that the ratio of vacancy oxygen values rise with the calcination temperature increasing (except CS-750). That is, increasing calcination temperature improves the relative vacancy oxygen concentration. Vacancy oxygen is an important spice for the redox catalyst, which is beneficial for the electro-catalytic activities of $\mathrm{CaSnO}_{3}$ for $\mathrm{H}_{2} \mathrm{O}_{2}$ generation. This is confirmed by the results of DFT theoretical calculation (see the following mechanism section).

Table 1 XPS spectra of O1s for the catalysts calcined at various temperatures.

\begin{tabular}{ccccc}
\hline Catalyst & Lattice O (\%) & Vacancy O (\%) & Adsorption O (\%) & Ratio of vacancy oxygen \\
\hline CS-550 & 55.3 & 35.6 & 9.1 & 0.55 \\
CS-650 & 45.7 & 44.2 & 10.1 & 0.79 \\
CS-750 & 54.1 & 40.8 & 5.0 & 0.69 \\
CS-800 & 51.3 & 43.9 & 4.8 & 0.78 \\
CS-850 & 41.1 & 53.5 & 5.4 & 1.15 \\
\hline
\end{tabular}

\section{Electro-catalytic activities for $\mathrm{H}_{2} \mathrm{O}_{2}$ generation}

Figure 8 shows the $\mathrm{H}_{2} \mathrm{O}_{2}$ generation rates vs potential ( $\mathrm{V}$ vs $\mathrm{Ag} / \mathrm{AgCl}$ ) without illumination over $\mathrm{CaSnO}_{3}$ catalysts calcined at different calcination temperatures. 


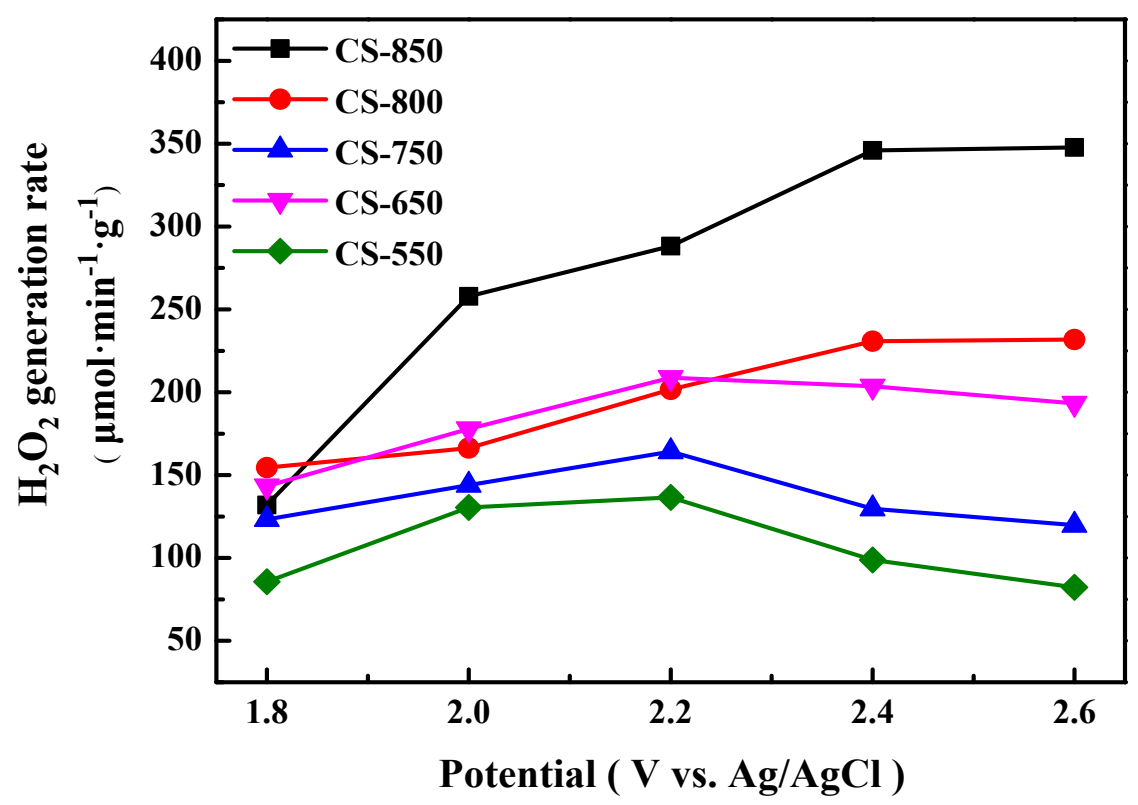

Figure 8 The $\mathrm{H}_{2} \mathrm{O}_{2}$ generation rates vs potential (V) without illumination over $\mathrm{CaSnO}_{3}$ catalysts.

As shown in the Figure 8, all of the catalysts are active for $2 \mathrm{e}-\mathrm{WOR}$ to generate $\mathrm{H}_{2} \mathrm{O}_{2}$, and the calcination temperature of the catalyst influences electro-catalytic performances obviously. This result demonstrates that although there is a few $\mathrm{SnO}_{2}$ impurities in the catalysts, $\mathrm{SnO}_{2}$ hardly contribute to activity due to both of catalytic activity and amount of $\mathrm{SnO}_{2}$ in the catalysts decreased with increasing calcination temperature. For CS-800 and CS-850, the rates of $\mathrm{H}_{2} \mathrm{O}_{2}$ production increase with the applied potentials. According to the results of XRD, the higher calcination temperature enhances the crystal formation of $\mathrm{CaSnO}_{3}$, which leads to better catalytic activity and higher $\mathrm{H}_{2} \mathrm{O}_{2}$ generation rates. For the three catalysts with lower calcination temperature (CS-550, CS-650 and CS-750), with the increase of applied potentials, the $\mathrm{H}_{2} \mathrm{O}_{2}$ production rates decreases after approaching the highest point of $2.2 \mathrm{~V}$ vs $\mathrm{Ag} / \mathrm{AgCl}$, demonstrating that the influence of applied potential on the $\mathrm{H}_{2} \mathrm{O}_{2}$ generation is limited. The applied potentials at highest production rate of $\mathrm{H}_{2} \mathrm{O}_{2}(2.2 \mathrm{~V}$ vs $\mathrm{Ag} / \mathrm{AgCl})$ for lower calcination temperature three catalysts are still much lower than that reported by Park et al., 3.0 V vs 
$\mathrm{Ag} / \mathrm{AgCl} .{ }^{18}$ Furthermore, for the $\mathrm{CaSnO}_{3}$ catalysts with calcination temperature of 800 and 850 ${ }^{\circ} \mathrm{C}$, the $\mathrm{H}_{2} \mathrm{O}_{2}$ generation rates increase originally with the applied potentials, and then keep stable. For the sample calcined at $850{ }^{\circ} \mathrm{C}$, the $\mathrm{H}_{2} \mathrm{O}_{2}$ generation rate approaches $347.7 \mu \mathrm{mol} \cdot \mathrm{min}^{-1} \cdot \mathrm{g}^{-1}$ at 2.6 V vs Ag/AgCl. Probably, there is an optimal potential window for $\mathrm{H}_{2} \mathrm{O}_{2}$ production, due to the competition between one-electron and four-electron oxidation with applied potential and calcination temperature. ${ }^{14}$

The stability of $\mathrm{CaSnO}_{3}$ for 2e-WOR was tested by measuring the concentration of $\mathrm{H}_{2} \mathrm{O}_{2}$ under several biases (2.2, 2.4 and $2.6 \mathrm{~V}$ vs $\mathrm{Ag} / \mathrm{AgCl})$ for $6 \mathrm{~h}$ under dark conditions for $\mathrm{CS}-850$. As the Figure 9 shown, the accumulation amount of $\mathrm{H}_{2} \mathrm{O}_{2}$ initially increases linearly and then towards stable after running $2 \mathrm{~h}$. The approaching saturation phenomenon probably is due to $\mathrm{H}_{2} \mathrm{O}_{2}$ decompose and oxidation at the higher concentration. ${ }^{18}$

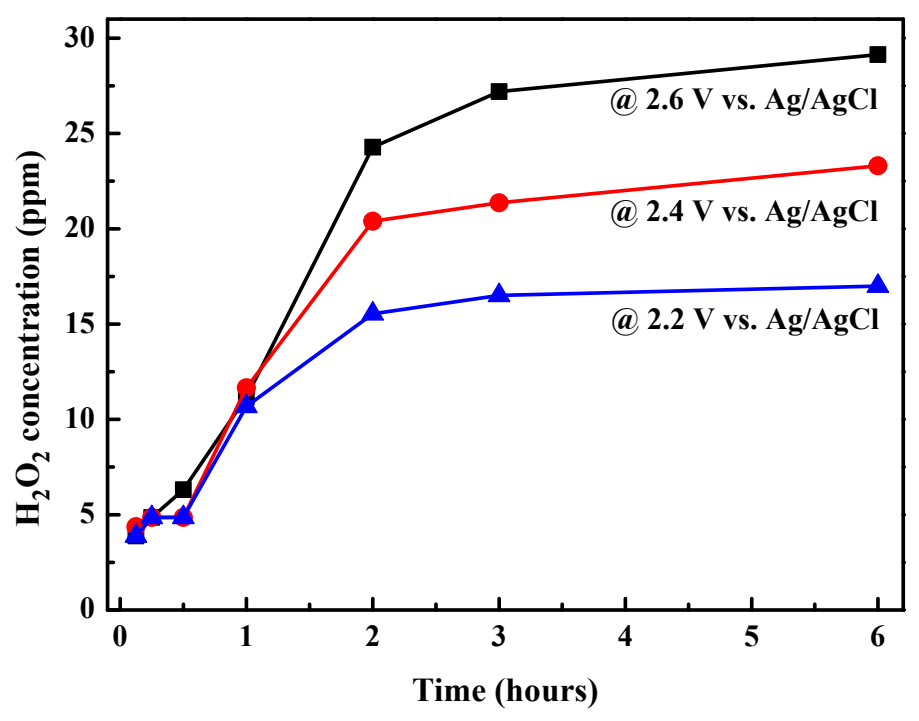

Figure 9 Stability of CS-850 electrode for $\mathrm{H}_{2} \mathrm{O}_{2}$ generation without illumination. 


\section{Electro-catalytic mechanism}

It is worth to note that the generation rate of $\mathrm{H}_{2} \mathrm{O}_{2}$ decreases in the sequence of CS-850>CS-800 $>$ CS-650 $>$ CS-750 $>$ CS-550, which matches the sequence of the ratio of vacancy oxygen values from XPS for samples with various calcination temperature, as shown in Figure 10. It means that 2e-WOR catalytic performance is closely related to the vacancy oxygen.

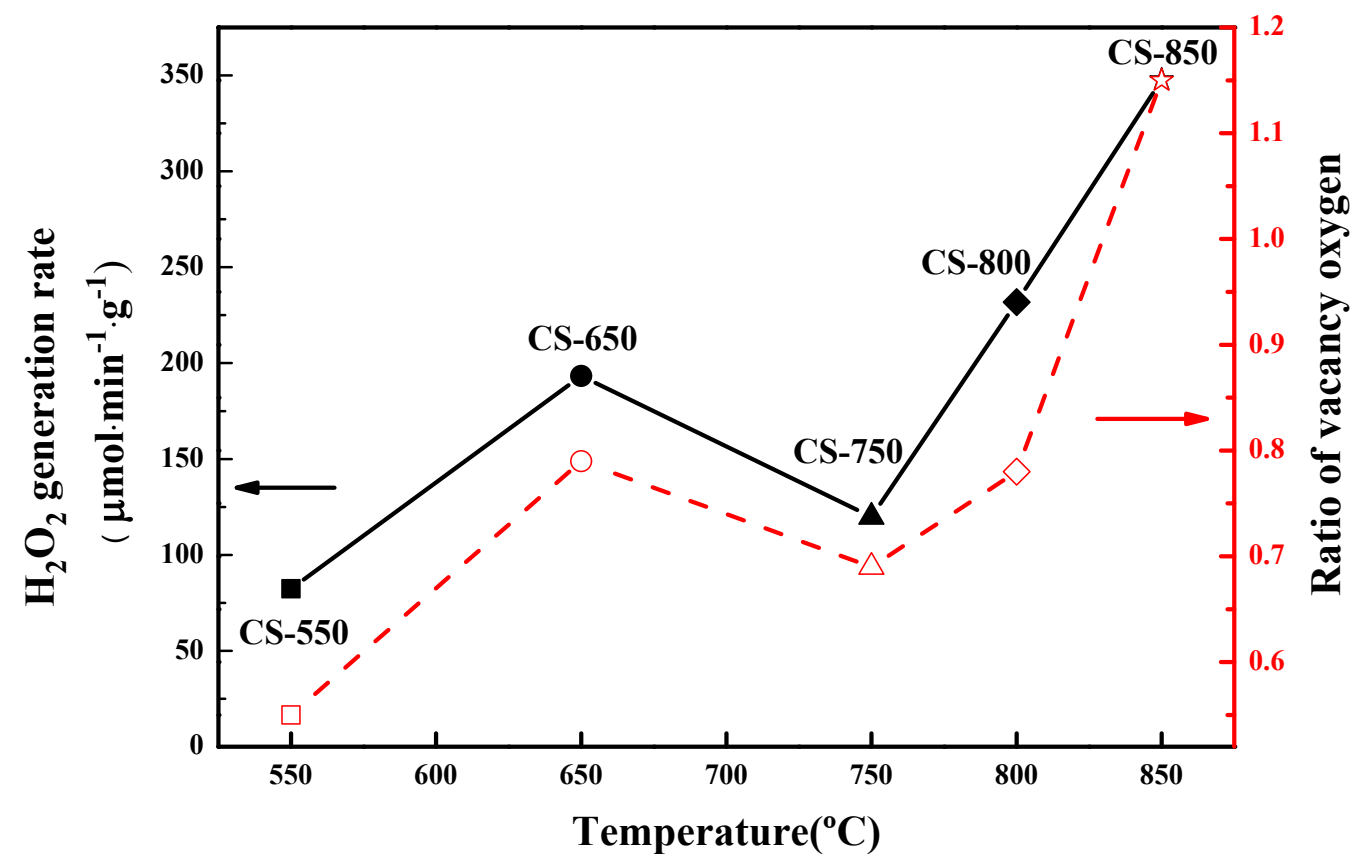

Figure $10 \mathrm{H}_{2} \mathrm{O}_{2}$ generation rate of $\mathrm{CaSnO}_{3}$ catalysts at $2.6 \mathrm{~V}$ vs $\mathrm{Ag} / \mathrm{AgCl}$ and the ratio of vacancy oxygen.

The 2e-WOR electrochemical system is in the $\mathrm{KHCO}_{3}$ solution, $\mathrm{pH}$ 8.3. The $\mathrm{OH}^{-}$concentration is much higher than $\mathrm{H}^{+}$in the solution and $\mathrm{H}_{2} \mathrm{O}_{2}$ should ionize to $\mathrm{HO}_{2}^{-}$(Equation $\mathrm{S} 6$ ) and maintains acid-base equilibrium. Using DFT calculation, the adsorption of $\mathrm{OH}^{-}$and $\mathrm{H}_{2} \mathrm{O}_{2}$ on the typical surface $\mathrm{CaSnO}_{3}(121)$ is systematically calculated. As shown in Figure S4, there are coordination-unsaturated $\mathrm{Sn}$ and $\mathrm{Ca}$ ions on $\mathrm{CaSnO}_{3}(121)$ surface. Our theoretical results show, Figure 11, that $\mathrm{OH}^{-}$strongly chemisorbs at the 5-coordinated $\mathrm{Sn}$ of $\mathrm{CaSnO}_{3}$ (121) with an 
adsorption energy of $-2.70 \mathrm{eV}$; while it does not adsorb at the site of surface $\mathrm{Ca}$ ion. Furthermore, $\mathrm{H}_{2} \mathrm{O}_{2}$ also adsorbs at the 5-coordinated $\mathrm{Sn}$ with adsorption energy of $-0.63 \mathrm{eV}$, which is much less than that of $\mathrm{OH}^{-}$. This indicates that the coordination-unsaturated $\mathrm{Sn}$ would be the active sites for $\mathrm{H}_{2} \mathrm{O}_{2}$ formation on $\mathrm{CaSnO}_{3}$ catalyst, and $\mathrm{H}_{2} \mathrm{O}_{2}$ would easily desorb from catalyst after formation. The transition state (TS) searching shows that the reaction barrier of two $\mathrm{OH}$ intermediates to form $\mathrm{H}_{2} \mathrm{O}_{2}$ is $2.11 \mathrm{eV}$; while the barrier of the reverse reaction is $0.73 \mathrm{eV}$. The distances between $\mathrm{O}$ and two $\mathrm{Sn}$ are $3.205 \AA$ and $2.955 \AA$, respectively. This is a relatively high activation energy indicating that $\mathrm{OH}^{-}$might be difficult to form $\mathrm{H}_{2} \mathrm{O}_{2}$ at normal temperature and pressure conditions without the help of applied electrical field.
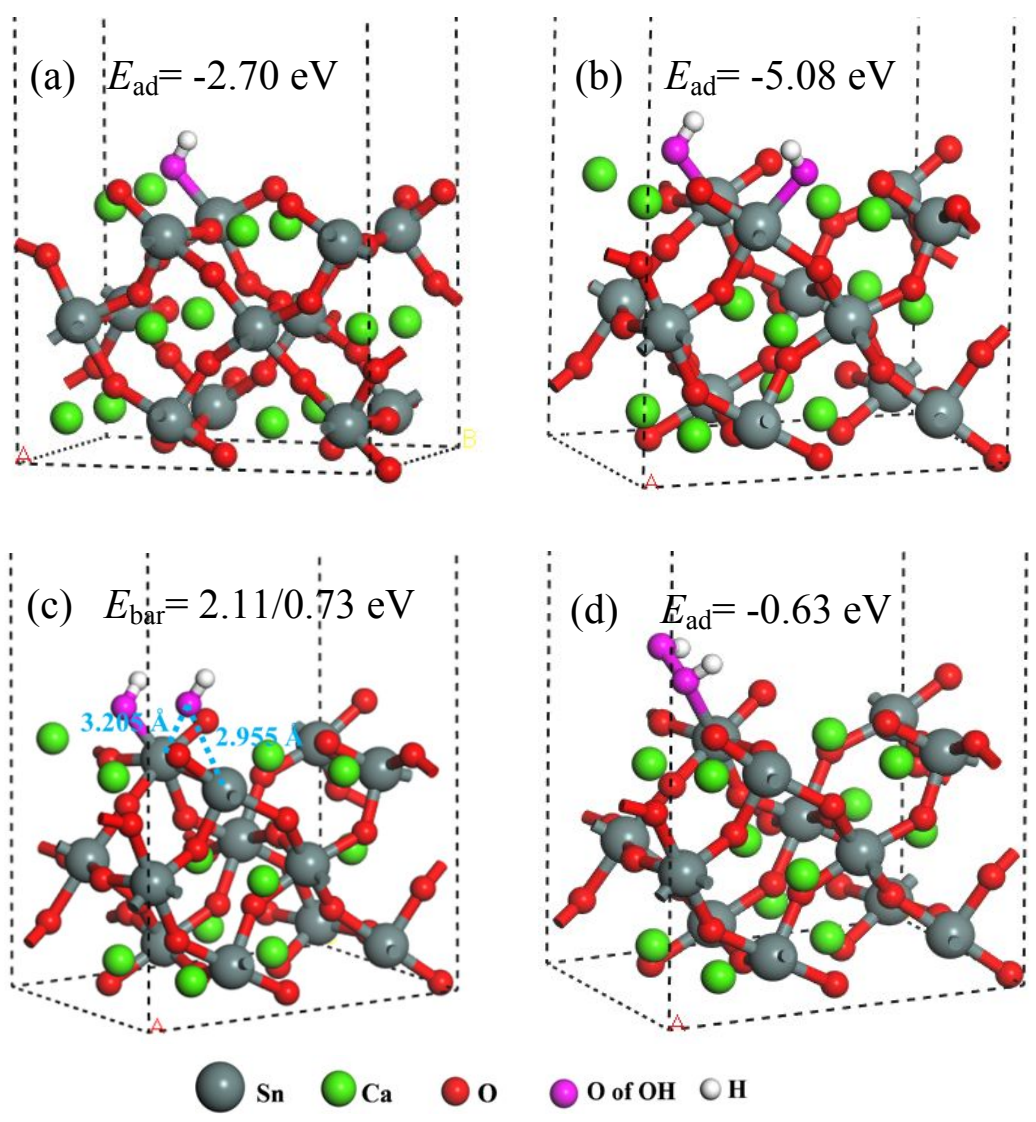

Figure $11 \mathrm{OH}$, TS and $\mathrm{H}_{2} \mathrm{O}_{2}$ on $\mathrm{CaSnO}_{3}$ (121). (a) $\mathrm{OH}^{-}$; (b) 2OH; (c) TS from $2 \mathrm{OH}$ to $\mathrm{H}_{2} \mathrm{O}_{2}$; (d) $\mathrm{H}_{2} \mathrm{O}_{2}$. 
DFT calculation results show that the active sites are the coordination-unsaturated Sn ions and easily adsorb the negative charge $\mathrm{OH}^{-}$from solution. From the theoretical calculation and the experimental results, the reaction mechanism is suggested. The $\mathrm{OH}^{-}$ion diffuses to the surface of $\mathrm{CaSnO}_{3}$ and is adsorbed on the active sites to form $\mathrm{OH}^{-}$ad (Equation 1). The $\mathrm{OH}^{-}$ad transfers an electron to the electrode ${ }^{30}$ and converts to neutral $\mathrm{OH}^{*}$ intermediate (Equation 2), which is still adsorbed on the same sites. Two adsorbed $\mathrm{OH}^{*}$ intermediates on the surface combine to form a neutral $\mathrm{H}_{2} \mathrm{O}_{2}$ molecule (Equation 3).

$$
\begin{gathered}
\mathrm{OH}^{-} \rightarrow \mathrm{OH}_{a d}^{-} \\
\mathrm{OH}_{a d}^{-} \rightarrow \mathrm{OH}^{*}+e^{-} \\
2 \mathrm{OH}^{*} \rightarrow \mathrm{H}_{2} \mathrm{O}_{2}
\end{gathered}
$$

The coordination-unsaturated $\mathrm{Sn}$ ion is the active sites obtained from DFT calculation which suggests the vacancy oxygen is present in the catalyst. XPS spectra exactly shows that the vacancy oxygen concentration rises with the calcination temperature increasing. Catalytic activities increase with vacancy oxygen concentration increasing. The theoretic calculation is consistent with the electro-catalytic activities. The positive correlation between the amount of coordination-unsaturated Sn ions and the ratio of vacancy oxygen values is observed. It suggests that higher vacancy oxygen concentration on the catalysts surface leads to higher electrocatalytic activities for $\mathrm{H}_{2} \mathrm{O}_{2}$ generation.

\section{Conclusion}

$\mathrm{CaSnO}_{3}$ electro-catalyst 2e-WOR is prepared with glucose as agent. $\mathrm{CaSnO}_{3}$ nanoparticles 
increase in sizes and amount with increasing calcination temperature. $\mathrm{CaSnO}_{3}$ catalyzed 2eWOR towards $\mathrm{H}_{2} \mathrm{O}_{2}$ at generation rate of $347.7 \mu \mathrm{mol} \cdot \mathrm{min}^{-1} \cdot \mathrm{g}^{-1}$ at $2.6 \mathrm{~V}$ vs $\mathrm{Ag} / \mathrm{AgCl}$ for the catalyst calcined $850{ }^{\circ} \mathrm{C}$. The phase composition and electro-catalytic performance of catalysts were obviously influenced by calcination temperature. There is positive correlation between concentration of vacancy oxygen and catalytic activity. Suggested mechanism is that $\mathrm{OH}^{-}$ adsorbs on the coordination-unsaturated $\mathrm{Sn}$ ions and transfers electron to form $\mathrm{OH}^{*}$ intermediate, then two adsorbed $\mathrm{OH}^{*}$ intermediates on the surface combine to form a neutral $\mathrm{H}_{2} \mathrm{O}_{2}$ molecule. The work opens a route for in-situ $\mathrm{H}_{2} \mathrm{O}_{2}$ generation directly from water oxidation and will benefit $\mathrm{H}_{2} \mathrm{O}_{2}$ applications.

\section{Supporting Information}

Supporting data and method and model using DFT calculation.

\section{Acknowledgments}

This work was accomplished under the support of National Nature Science Foundation of China (No 51776216) and Tianjin Weiming Technology Co. Ltd \& Tianjin University of Science and Technology (No. 1900030001).

We sincerely thank Professor Botao Teng for the theoretical support of density functional theory calculation by VASP and the useful discussion of the active sites and reaction mechanism of $\mathrm{H}_{2} \mathrm{O}_{2}$ formation.

\section{Conflict of interest}


The authors report no conflict of interest.

\section{References}

(1) Sharma, K. P.; Sharma, S.; Sharma, Subhasini; Singh, P. K.; Kumar, S.; Grover, R.; Sharma, P. K. A comparative study on characterization of textile wastewaters (untreated and treated) toxicity by chemical and biological tests. Chemosphere 2007, 69 (1), 48-54, DOI 10.1016/j.chemosphere.2007.04.086.

(2) Zollinger, H. Syntheses, properties and applications of organic dyes and pigments. Colour Chemistry (2nd Ed). VCH Publishers, 1991, 496.

(3) Glaze, W. H.; Kang, J.-W.; Chapin, D. H. The chemistry of water treatment processes involving ozone, hydrogen peroxide and ultraviolet radiation. Ozone: Sci. Eng. 1987, 9 (4), 335-352, DOI $10.1080 / 01919518708552148$.

(4) Casado, J. Towards industrial implementation of Electro-Fenton and derived technologies for wastewater treatment: A review. J. Environ. Chem. Eng. 2019, 7 (1), 102823, DOI 10.1016/j.jece.2018.102823.

(5) Campos-Martin, J. M.; Blanco-Brieva, G.; Fierro, J. L. Hydrogen peroxide synthesis: an outlook beyond the anthraquinone process. Angew. Chem. Int. Ed. 2006, 45 (42), 6962-6984, DOI 10.1002/chin.200703216.

(6) Brillas, E.; Garrido, J. A.; Rodríguez, R. M.; Arias, C.; Cabot, P. L.; Centellas, F. Wastewaters by Electrochemical Advanced Oxidation Processes Using a BDD Anode and Electrogenerated $\mathrm{H}_{2} \mathrm{O}_{2}$ with Fe(II) and UVA Light as Catalysts. Port. Electrochim. Acta 2008, 26 (1), 15-46, DOI 10.4152/pea.200801015.

(7) Oturan, M. A.; Aaron, J.-J. Advanced Oxidation Processes in Water/Wastewater Treatment: Principles and Applications. A Review. Crit. Rev. Environ. Sci. Technol. 2014, 44 (23), 2577-2641, DOI 10.1080/10643389.2013.829765.

(8) Haber, F.; Weiss, J. The catalytic decomposition of hydrogen peroxide by iron salts. Proc. R. Soc. London, Ser. A 1934, 147 (861), 332-351, DOI 10.1098/rspa.1934.0221.

(9) Perry, S. C.; Pangotra, D.; Vieira, L.; Csepei, L.-I.; Sieber, V.; Wang, L.; de León, C. P.; Walsh, F. C. Electrochemical synthesis of hydrogen peroxide from water and oxygen. Nat. Rev. Chem. 2019, 3 (7), 442-458, DOI 10.1038/s41570-019-0110-6.

(10) Yamanaka, I.; Onizawa, T.; Takenaka, S.; Otsuka, K. Direct and continuous production of hydrogen peroxide with 93\% selectivity using a fuel-cell system. Angew. Chem. Int. Ed. 2003, 42 (31), 3653-3655, DOI 10.1002/ange.200351343. 
(11) Shi, X.; Siahrostami, S.; Li, G.-L.; Zhang, Y.; Chakthranont, P.; Studt, F.; Jaramillo, T. F.; Zheng, X.; Nørskov, J. K. Understanding activity trends in electrochemical water oxidation to form hydrogen peroxide. Nat. Commun. 2017, 8 (1), 1-6, DOI 10.1038/s41467-017-00585-6.

(12) Bard, A. J.; Parsons, R.; Jordan, J. Standard potentials in aqueous solution. Routledge, 2017.

(13) Kruusenberg, I.; Matisen, L.; Jiang, H.; Huuppola, M.; Kontturi, K. S.; Tammeveski, K. Electrochemical reduction of oxygen on double-walled carbon nanotube modified glassy carbon electrodes in acid and alkaline solutions. Electrochem. Commun. 2010, 12 (7), 920-923, DOI 10.1016/j.elecom.2010.04.021.

(14) Fuku, K.; Miyase, Y.; Miseki, Y.; Gunji, T.; Sayama, K. Enhanced oxidative hydrogen peroxide production on conducting glass anodes modified with metal oxides. ChemistrySelect 2016, 1 (18), 57215726, DOI 10.1002/slct.201601469.

(15) Fuku, K.; Sayama, K. Efficient oxidative hydrogen peroxide production and accumulation in photoelectrochemical water splitting using a tungsten trioxide/bismuth vanadate photoanode. Chem. Commun. 2016, 52 (31), 5406-5409, DOI 10.1039/c6cc01605g.

(16) Shin, S. S.; Yeom, E. J.; Yang, W. S.; Hur, S.; Kim, M. G.; Im, J.; Seo, J.; Noh, J. H.; Seok, S. I. Colloidally prepared La-doped $\mathrm{BaSnO}_{3}$ electrodes for efficient, photostable perovskite solar cells. Science 2017, 356 (6334), 167-171, DOI 10.1126/science.aam6620.

(17) Kruithof, J. C.; Kamp, P. C.; Martijn, B. J. UV/ $\mathrm{H}_{2} \mathrm{O}_{2}$ treatment: a practical solution for organic contaminant control and primary disinfection. Ozone: Sci. Eng. 2007, 29 (4), 273-280, DOI 10.1080/01919510701459311.

(18) Park, S. Y.; Abroshan, H.; Shi, X.; Jung, H. S.; Siahrostami, S.; Zheng, X. $\mathrm{CaSnO}_{3}$ : an electrocatalyst for two-electron water oxidation reaction to form $\mathrm{H}_{2} \mathrm{O}_{2}$. ACS Energy Lett. 2018, 4 (1), 352-357, DOI 10.1021/acsenergylett.8b02303.

(19) Huckaba, C. E.; Keyes, F. G. The Accuracy of Estimation of Hydrogen Peroxide by Potassium Permanganate Titration. J. Am. Chem. Soc. 1948, 70 (4), 1640-1644, DOI 10.1021/ja01184a098.

(20) Lu, Z.; Liu, J.; Tang, Y.; Li, Y. Hydrothermal synthesis of $\mathrm{CaSnO}_{3}$ cubes. Inorg. Chem. Commun. 2004, 7 (6), 731-733, DOI 10.1016/j.inoche.2004.03.030.

(21) Perry, C.; Khanna, B.; Rupprecht, G. Infrared studies of perovskite titanates. Phys. Rev. 1964, 135 (2A), A408, DOI 10.1103/PhysRev.135.A408.

(22) Moreira, E.; Barboza, C.; Albuquerque, E.; Fulco, U.; Henriques, J.; Araújo, A. Vibrational and thermodynamic properties of orthorhombic $\mathrm{CaSnO}_{3}$ from DFT and DFPT calculations. J. Phys. Chem. Solids 2015, 77, 85-91, DOI 10.1016/j.jpcs.2014.09.016. 
(23) Zheng, H. L.; Zhang, Z. C.; Zhou, J. G.; Yang, S. S.; Zhao, J. Vibrational spectra of $\mathrm{CaGa}_{2} \mathrm{O}_{4}$, $\mathrm{Ca}_{2} \mathrm{GeO}_{4}, \mathrm{CaIn}_{2} \mathrm{O}_{4}$ and $\mathrm{CaSnO}_{3}$ prepared by electrospinning. Appl. Phys. A 2012, 108 (2), 465-473, DOI 10.1007/s00339-012-6916-4.

(24) Ansari, F.; Sobhani, A.; Salavati-Niasari, M. Simple sol-gel synthesis and characterization of new $\mathrm{CoTiO}_{3} / \mathrm{CoFe}_{2} \mathrm{O}_{4}$ nanocomposite by using liquid glucose, maltose and starch as fuel, capping and reducing agents. J. Colloid Interface Sci. 2018, 514, 723-732, DOI 10.1016/j.jcis.2017.12.083.

(25) Zhong, F.; Zhuang, H.; Gu, Q.; Long, J. Structural evolution of alkaline earth metal stannates $\mathrm{MSnO}_{3}(\mathrm{M}=\mathrm{Ca}, \mathrm{Sr}$, and $\mathrm{Ba})$ photocatalysts for hydrogen production. $R S C A d v$. 2016, 6 (48), 4247442481, DOI 10.1039/C6RA05614H.

(26) Sharma, N.; Shaju, K.; Rao, G. S.; Chowdari, B. Anodic behaviour and X-ray photoelectron spectroscopy of ternary tin oxides. J. Power Sources 2005, 139 (1-2), 250-260, DOI 10.1016/j.jpowsour.2004.06.057.

(27) Gao, Y.; Zhi, C.; Cui, P.; Zhang, K. A. I.; Lv, L.-P.; Wang, Y. Halogen-functionalized triazinebased organic frameworks towards high performance supercapacitors. Chem. Eng. J. 2020, 400, DOI 10.1016/j.cej.2020.125967.

(28) Teraoka, Y.; Yoshimatsu, M.; Yamazoe, N.; Seiyama, T. Oxygen-sorptive properties and defect structure of perovskite-type oxides. Chem. Lett. 1984, 13 (6), 893-896, DOI 10.1246/cl.1984.893.

(29) Zhang, N.; Chen, D.; Niu, F.; Wang, S.; Qin, L.; Huang, Y. Enhanced visible light photocatalytic activity of Gd-doped $\mathrm{BiFeO}_{3}$ nanoparticles and mechanism insight. Sci Rep 2016, 6, 26467, DOI $10.1038 /$ srep26467.

(30) Miyase, Y.; Iguchi, S.; Miseki, Y.; Gunji, T.; Sayama, K. Electrochemical $\mathrm{H}_{2} \mathrm{O}_{2}$ Production and Accumulation from $\mathrm{H}_{2} \mathrm{O}$ by Composite Effect of $\mathrm{Al}_{2} \mathrm{O}_{3}$ and $\mathrm{BiVO}_{4}$. J. Electrochem. Soc. 2019, 166 (13), H644-H649, DOI 10.1149/2.0561913jes. 
For Table of Contents Use Only.

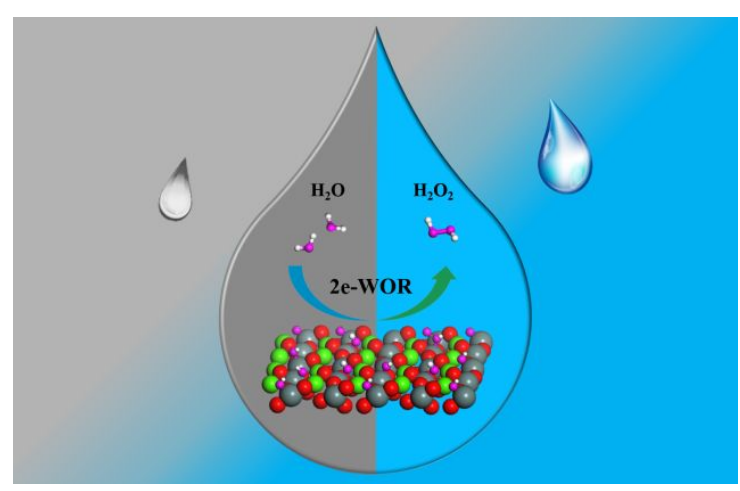

\section{Synopsis:}

In-situ generation of hydrogen peroxide from a sustainable electrochemical two-electron water oxidation opens a new route for green chemistry. 